\title{
Cardiac, skeletal, and ocular abnormalities in patients with Marfan's syndrome and in their relatives Comparison with the cardiac abnormalities in patients with kyphoscoliosis
}

\author{
L BRUNO, S TREDICI, M MANGIAVACCHI, V COLOMBO, G F MAZZOTTA, \\ C R SIRTORI
}

From the Cardiovascular Division "De Gasperis" Niguarda Ca Guarda Hospital, Milan, Italy

SUMMARY Polygraphic (including apexcardiograms and carotid pulse tracings) and $M$ mode echocardiographic examinations were carried out in 34 symptomatic patients with Marfan's syndrome; similar studies were performed in 32 relatives and in 34 young patients with kyphoscoliotic disease. The purpose of these investigations was to determine the association between cardiac and oculoskeletal abnormalities and to identify specific patterns of disease with a poor prognosis.

Polygraphic tests showed significant changes in all patients with Marfan's syndrome: $74 \%$ showed the apical systolic click and murmur of mitral valve prolapse; $48 \%$ had the diastolic murmur of aortic regurgitation; isolated mitral valve prolapse was found in $52 \%, 26 \%$ had isolated aortic regurgitation, and $22 \%$ had a combination of the two. Echocardiographic changes were also found in all patients: $79 \%$ had aortic root dilatation; $48 \%$ fluttering of the anterior mitral leaflet; $79 \%$ mitral valve prolapse, mostly pansystolic; $34 \%$ both mitral prolapse and aortic root dilatation; and $34 \%$ left ventricular dilatation. The severities of the cardiac and oculoskeletal abnormalities were not correlated. The high prevalence of mitral valve prolapse found in these patients, which did not vary with age or sex, was also present in their relatives: mitral prolapse was present in $38 \%$ and aortic dilatation, with or without regurgitation, in 14\%. Four of the relatives had clearcut Marfan's syndrome, and at least four others a forme fruste. The metacarpal index was abnormal in $41 \%$ of the relatives; ocular abnormalties were rare. In kyphoscoliotic patients only an increase in the prevalence of mitral prolapse (18.2\% in women, none in men) was found.

These findings underline a complex pattern of association between cardiac, ocular, and skeletal abnormalities in patients with Marfan's syndrome and confirm an appreciable inheritability of several of the markers of the disease.

Marfan's syndrome is a generalised inherited disorder of the connective tissue, transmitted as autosomal, non-sex-linked, with variable penetrance. The main abnormalities are related to the skeleton, ${ }^{1}$ eyes, ${ }^{2}$ and cardiovascular system. ${ }^{3}$ The clinical picture can easily be recognised in patients with long thin limbs, arachnodactyly, chest malformations, ectopia lentis, and dilatation of the ascending aorta. ${ }^{4}$ Diagnosis is more

Requests for reprints to Dr Luigi Bruno, Divisione Cardiologica De Gasperis, Niguarda "Ca Guarda" Hospital, Milan, Italy.

Accepted for publication 2 August 1983 difficult in patients with only some of the typical external signs. ${ }^{356}$ The prognosis is related to the cardiovascular changes, with a reduced overall survival. In a group of 257 patients, Murdoch et al noted 72 deaths, $93 \%$ of which were attributable to cardiovascular complications ${ }^{7}$ : these included rupture or dissection of a thoracic aortic aneurysm, aortic regurgitation, heart failure, and myocardial infarction. According to McKusick, the downward course of the disease is rapid, after the onset of cardiovascular symptoms, generally leading to a fatal outcome within two years. ${ }^{3}$ The early detection of patients with Marfan's syndrome, as well as their appropriate clinical evaluation, 
is therefore of considerable clinical importance. ${ }^{89}$ Tests should also be carried out on the relatives of patients with Marfan's syndrome using non-invasive methods, ${ }^{610}$ and possibly on patients with other forms of connective tissue disease, who are likely to have changes typical of Marfan's syndrome.

Mechanocardiography and echocardiography allow early and quantitative recognition of cardiovascular changes. In this study the polygraphic and echocardiographic features of Marfan's syndrome-for example, the incidence of mitral valve prolapse and aortic root dilatation with or without aortic regurgitation-were identified in a continuous series of patients referred, usually with symptoms, between 1976 and 1982. Our objective was to acquire a better understanding of the evolution of the cardiovascular changes; to evaluate their prevalence and severity, comparing them with the skeletal and ocular abnormalities which might be present, and, finally, to identify subjects with a particularly unfavourable prognosis. The skeletal, ocular, and cardiovascular changes were also determined in a group of relatives of patients with Marfan's syndrome. Finally, on the premise that Marfan's syndrome represents an extreme form of a general disease of the connective tissue, which can, however, manifest itself in a less severe form, cardiological abnormalities were also looked for in a group of asymptomatic subjects with severe kyphoscoliosis.

\section{Subjects and methods}

\section{PATIENTS}

Thirty four patients with Marfan's syndrome were studied, and their clinical data are given in Table 1. They were referred to our centre either because of subjective symptoms (one had aortic dissection) or because of abnormalities on cardiac examination and instrumental tests, or because of both. Of the 34, 26 were males and eight females. Four boys and two girls were under 16 years of age, mean age being $23.8 \pm 11.7$ years (range $9-53$ ) in males and $23.0 \pm 8.8$ years (range 11-38) in females. Twenty three underwent a polygraphic examination, 29 echocardiography, and 18 both tests. The height span difference was determined in 29 and metacarpal index in 20. Twenty four underwent ocular examination.

Thirty two relatives of nine patients with Marfan's

Table 1 Clinical data on the 34 patients with Marfan's syndrome

\begin{tabular}{|c|c|c|c|c|c|c|c|c|}
\hline Case No & Sex & $\begin{array}{l}\text { Age } \\
\text { (yr) }\end{array}$ & $\begin{array}{l}\text { Weight } \\
(\mathbf{k g})\end{array}$ & $\begin{array}{l}\text { Height } \\
(\mathrm{cm})\end{array}$ & $\begin{array}{l}\text { Span } \\
(\mathrm{cm})\end{array}$ & $\begin{array}{l}\text { Height span } \\
\text { difference }(\mathrm{cm})\end{array}$ & $\begin{array}{l}\text { Metacarpal } \\
\text { index }\end{array}$ & Ocular state \\
\hline $\begin{array}{r}1 \\
2 \\
3 \\
4 \\
5 \\
6 \\
7 \\
8 \\
9 \\
10 \\
11 \\
12 \\
13 \\
14 \\
15 \\
16 \\
17 \\
18 \\
19 \\
20 \\
21 \\
22 \\
23 \\
24 \\
25 \\
26 \\
27 \\
28 \\
29 \\
30 \\
31 \\
32 \\
33 \\
34\end{array}$ & $\begin{array}{l}\mathbf{M} \\
\mathbf{M} \\
\mathbf{M} \\
\mathbf{M} \\
\mathbf{F} \\
\mathbf{M}\end{array}$ & $\begin{array}{r}13 \\
17 \\
30 \\
17 \\
22 \\
19 \\
11 \\
9 \\
12 \\
23 \\
11 \\
24 \\
27 \\
19 \\
53 \\
16 \\
17 \\
47 \\
13 \\
16 \\
27 \\
25 \\
21 \\
29 \\
28 \\
23 \\
21 \\
51 \\
21 \\
37 \\
16 \\
38 \\
21 \\
31\end{array}$ & $\begin{array}{l}58 \\
60 \\
72 \\
64 \\
50 \\
69 \\
37 \\
37 \\
34 \\
57 \\
35 \\
65 \\
67 \\
70 \\
67 \\
68 \\
67 \\
68 \\
56 \\
60 \\
50 \\
65 \\
45 \\
54 \\
62 \\
68 \\
69 \\
72 \\
58 \\
75 \\
75 \\
64 \\
70 \\
60 \\
62\end{array}$ & $\begin{array}{l}174 \\
185 \\
176 \\
182 \\
163 \\
185 \\
160 \\
162 \\
145 \\
182 \\
147 \\
178 \\
184 \\
185 \\
176 \\
186 \\
184 \\
187 \\
182 \\
184 \\
170 \\
180 \\
170 \\
176 \\
185 \\
188 \\
188 \\
180 \\
182 \\
185 \\
188 \\
182 \\
184 \\
185\end{array}$ & $\begin{array}{l}183 \\
194 \\
184 \\
192 \\
165 \\
191 \\
167 \\
170 \\
-190 \\
1193 \\
192 \\
194 \\
182 \\
193 \\
176 \\
190 \\
193 \\
178 \\
189 \\
184 \\
195 \\
196 \\
197 \\
188 \\
190 \\
197 \\
190 \\
192 \\
194\end{array}$ & $\begin{array}{r}9 \\
9 \\
8 \\
10 \\
2 \\
6 \\
7 \\
8 \\
8 \\
5 \\
8 \\
9 \\
6 \\
9 \\
9 \\
8 \\
9 \\
8 \\
9 \\
8 \\
10 \\
8 \\
9 \\
8 \\
8 \\
9 \\
8 \\
\end{array}$ & $\begin{array}{l}9.5 \\
\overline{8} .6 \\
- \\
8.8 \\
8.4 \\
- \\
8.8 \\
8.5 \\
8.6 \\
8.6 \\
8.5 \\
8.0 \\
- \\
9.8 \\
8.5 \\
- \\
- \\
- \\
10.6 \\
8.5 \\
8.9 \\
8.0 \\
- \\
8.5 \\
8.5 \\
8.4 \\
8.6\end{array}$ & $\begin{array}{l}++ \\
++ \\
\overline{0} \\
0 \\
+ \\
0 \\
+ \\
- \\
+ \\
+ \\
+ \\
+ \\
+ \\
+ \\
++ \\
+ \\
+ \\
+ \\
++ \\
+ \\
+ \\
+ \\
+ \\
+ \\
+ \\
++ \\
++ \\
+\end{array}$ \\
\hline
\end{tabular}

* Subjects classified as having probable $(++)$, possible $(+)$, or no $(0)$ ocular signs of Marfan's syndrome.

Cases 15,6, and 20 are father and two children, cases 30 and 7 are father and daughter, and cases 5 and 24 are niece and aunt.

Cases 24, 25, 27, 28, and 32 underwent operations for massive aortic regurgitation; case 30 underwent operation for aortic dissection; cases 24 , 25 , and 30 are dead. 
syndrome were similarly considered; there were 17 females and 15 males, with six girls and two boys under 16 years of age. Mean ages of the relatives were $30.5 \pm 16.4$ years (range $5-54$ ) in males and $28.5 \pm 15 \cdot 3$ years (range 11-55) in females. M Mode echocardiography was performed in 29 , skeletal examination in 17 , and ophthalmological evaluation in 20.

A continuous series of 34 subjects with severe kyphoscoliosis, evaluated at the orthopaedic division of this hospital, were similarly examined. The group included 12 males and 22 females, mean age being $16 \cdot 2 \pm 5 \cdot 0$ years (range $12-23$ ) in males and $16 \cdot 1 \pm 5 \cdot 1$ years (range 11-31) in females. Echocardiography and mechanocardiography were performed in all: in eight cases pharmacological tests (amyl nitrite, methoxamine) and cross sectional echocardiography were necessary to confirm the presence of mitral valve prolapse. Height and arm span were determined in all and metacarpal index in 20 . None had ocular symptoms and the ophthalmological examination was not performed.

\section{METHODS}

\section{Cardiac evaluation}

The polygraphic tests were recorded with an ElemaShonander Mingograph 82 apparatus at a paper speed of $100 \mathrm{~mm} / \mathrm{s}$. Tracings were analysed independently by at least two cardiologists for the presence of systolic clicks and murmurs and diastolic regurgitant murmurs. Carotid pulse tracings were examined carefully, paying particular attention to the plateau and dicrotic notch and wave. In the morphological evaluation of the apexcardiogram particular attention was paid to the systolic plateau and to the a wave amplitude.

$M$ mode echocardiograms were performed using a Smith Kline Ekoline 20 echocardiograph, with a 2.5 $\mathrm{MHz}$ piezoelectric crystal transducer $(1.3 \mathrm{~cm}$ internal diameter). Tracings were recorded with a Honeywell strip chart fibreoptic instrument. The following indices were determined. (1) Aortic diameter (absolute value), which was considered increased in adults when it exceeded $37 \mathrm{~mm}$. In subjects under 16 years it was always related to the body surface area. (2) Aortic diameter (related to the body surface area), which was considered increased in adults when it exceeded 22 $\mathrm{mm} / \mathrm{m}^{2}$ body surface area. For patients under 16 years the following criteria were applied: aortic dilatation was considered present when aortic diameter exceeded $15 \mathrm{~mm}$ in patients with body surface areas of less than $0.5 \mathrm{~m}^{2} ; 22 \mathrm{~mm}$ in patients with surface areas of 0.6 to $1.0 \mathrm{~m}^{2} ; 27 \mathrm{~mm}$ in patients with surface areas of 1.1 to $1.5 \mathrm{~m}^{2}$; and $28 \mathrm{~mm}$ in patients with surface areas greater than $1.5 \mathrm{~m}^{2}$. (3) The ratio of left atrium to aorta was considered decreased when $\leqslant 0.07$.
The criteria suggested by Brown et al ${ }^{11}$ were followed to evaluate the aortic root dilatation, which was considered present when two of the above criteria were positive.

Mitral valve prolapse was diagnosed when systolic posterior movements of both mitral leaflets were present on the echocardiogram, with leaflet separation of at least $3 \mathrm{~mm}$. Prolapses were divided into pansystolic and mid-end systolic, according to the timing of the posterior mitral leaflet backward movement. During diastole the echocardiogram often shows an anterior movement of the posterior leaflet. The presence of diastolic fluttering of the mitral leaflets, particularly of the anterior one, was regarded as a sign of aortic regurgitation.

The following values were also calculated. (1) Left ventricular end diastolic diameter: in adults normal values were $35-56 \mathrm{~mm}$ (corrected for body surface area $19 / 33 \mathrm{~mm} / \mathrm{m}^{2}$ ) and in children with body surface areas less than $0.5 \mathrm{~m}^{2}$ normal values were $13-32 \mathrm{~mm}$; for children with surface areas of $0.6-1.0 \mathrm{~m}^{2}$ normal values were $24-42 \mathrm{~mm}$; and for children with surface areas of $1 \cdot 1-1.5 \mathrm{~m}^{2}$ normal values were $33-47 \mathrm{~mm}$. (2) Shortening fraction, which was calculated using the formula:

end diastolic diameter-end systolic diameter end diastolic diameter $\times 100$

(normal value $\geqslant 30 \%$ ). (3) Mean rate of circumferential fibre shortening, which was calculated using the formula:

end diastolic diameter-end systolic diameter end diastolic diameter $\times$ left ventricular ejection time (normal value 1.0-1.9/s). The presence of paradoxical motions of the posterior aortic wall was also investigated. ${ }^{12}$

\section{Skeletal evaluation}

Body height and arm span were considered abnormal if the span exceeded the height by $7.6 \mathrm{~cm} .{ }^{13}$ Metacarpal index (ratio between the total axial length of the second, third, fourth, and fifth metacarpals of the right hand determined by $x$ ray examination in the posterior anterior position, and the total width of the same metacarpals at their mid-points) was measured: the ratio of 8.4 or more was considered abnormal and values between 8.0 and 8.3 as doubtful. Kyphoscoliosis, vertebral abnormalities, long ribs, clavicles, or toes, pectus exavatum, and pectus carinatum were not considered diagnostic of Marfan's syndrome. Kyphoscoliosis was considered severe if evident in the upright position.

\section{Ophthalmological evaluation}

Subjects were classified as having probable, possible, or no ocular signs of Marfan's syndrome. ${ }^{9}$ Subjects 
with subluxation of the lenses and abnormalities of the anterior chamber angle were classified as probable cases of Marfan's syndrome. Lenses, in these cases, are typically small and globular (spherophakia) and may be associated with coloboma and localised nonprogressive dot opacities, iridodonesis, hypoplasia of the iris, poor dilatation of the pupils, secondary glaucoma, various forms of peripheral degeneration, and detachment of the retina. ${ }^{214}$ Subjects with normal lenses, but with abnormalities of the anterior chamber angle, were classified as possible cases of Marfan's syndrome. Some subjects had other ocular abnormalities (myopia, astigmatism, exotropia, or lattice degeneration), often occurring in conjunction with Marfan's syndrome. These abnormalities are very common in the general population and are therefore not diagnostic of Marfan's syndrome.

\section{Results}

\section{PATIENTS WITH MARFAN'S SYNDROME}

\section{Polygraphic findings}

Substantial changes were found in all patients with Marfan's syndrome (Table 2). A non-ejection apical systolic click and murmur were found in $74 \%$ and in most cases both a mesosystolic click and mid-end systolic murmur were present. A diastolic murmur of aortic regurgitation was found in $48 \%$, a polygraphic pattern of isolated mitral valve prolapse in $52 \%$, a polygraphic pattern of isolated aortic regurgitation in $26 \%$, and a polygraphic pattern of both mitral valve prolapse and aortic regurgitation was found in $22 \%$.

The carotid pulse tracing was also recorded, and in six of 11 with aortic regurgitation (55\%) a systolic bisferiens plateau was noted. In general, the dicrotic notch was well preserved in these subjects, the dicrotic wave being normal or enlarged. Systolic time intervals were normal in all but one with mitral valve prolapse and aortic regurgitation, presenting with a shortened corrected left ventricular ejection time and an increased ratio of pre-ejection period to left ventricular ejection time.

The apexcardiogram was recorded in 20 patients. The a wave amplitude was increased in six (30\%), four with aortic regurgitation and two with both aortic regurgitation and mitral valve prolapse. The systolic plateau had a normal configuration in $11(55 \%)$, the mid-systolic notch being synchronous with the click in seven (35\%) (Fig. 1). A hypertrophic configuration (ogival shape) was seen in two cases.

\section{Echocardiographic findings}

Abnormalities on the echocardiogram pattern were found in all patients with Marfan's syndrome. In 79\% the intrapericardial aorta was considerably dilated (Fig. 2 and 3). This percentage fell to $55 \%$ (Table 3), however, when all three diagnostic criteria were applied. This finding was most prominent in male patients, even those under 16 years, thus confirming the observation ${ }^{11}$ that in patients with Marfan's syndrome dilatation of the aortic root is prevalent in males. Anterior mitral leaflet fluttering indicative of aortic regurgitation (Fig. 4) was noted in $48 \%$, mainly male patients older than 16 years, both associated with mitral valve prolapse and isolated (Tables 4 and 6). A clearcut echocardiographic picture of mitral valve prolapse was found in $79 \%$, essentially charac-

Table 2 Polygraphic findings in patients with Marfan's syndrome

\begin{tabular}{|c|c|c|c|c|c|c|c|}
\hline & \multicolumn{3}{|c|}{ Male patients } & \multicolumn{3}{|c|}{ Female patients } & \multirow[t]{2}{*}{ Total (\%) } \\
\hline & $<16$ years & Adults & Total (\%) & $<16$ years & Adults & Total (\%) & \\
\hline $\begin{array}{l}\text { No of patients } \\
\text { Normal findings } \\
\text { Apical systolic murmur } \\
\text { Pansystolic } \\
\text { Mesotelesystolic } \\
\text { Click } \\
\text { Mesosystolic } \\
\text { Protosystolic } \\
\text { Proto + mesosystolic } \\
\text { Diastolic regurgitant murmurt } \\
\text { Protodiastolic } \\
\text { Proto-mesodiastolic } \\
\text { Pandiastolic } \\
\text { Apical systolic click and murmur aloneł } \\
\text { Diastolic regurgitant murmur alone\$ } \\
\text { Apical systolic click and murmur } \\
+ \text { diastolic regurgitant murmur }\end{array}$ & $\begin{array}{l}3 \\
0 \\
3 \\
1 \\
2 \\
3 \\
3 \\
0 \\
0 \\
0 \\
0 \\
0 \\
0 \\
3 \\
0 \\
0\end{array}$ & $\begin{array}{r}15 \\
0 \\
11 \\
2 \\
9 \\
11 \\
7 \\
2 \\
2 \\
9 \\
4 \\
3 \\
2 \\
6 \\
4 \\
5\end{array}$ & $\begin{array}{l}18 \\
0 \\
14(78)^{\star} \\
3 \\
11 \\
14(78) \\
10 \\
2 \\
2 \\
9(50) \\
4 \\
3 \\
2 \\
9(50) \\
4(22) \\
5(28)\end{array}$ & $\begin{array}{l}1 \\
0 \\
1 \\
0 \\
1 \\
1 \\
1 \\
0 \\
0 \\
0 \\
0 \\
0 \\
0 \\
1 \\
0 \\
0\end{array}$ & $\begin{array}{l}4 \\
0 \\
2 \\
0 \\
2 \\
2 \\
2 \\
0 \\
0 \\
2 \\
0 \\
2 \\
0 \\
2 \\
2 \\
0\end{array}$ & $\begin{array}{l}5 \\
0 \\
3(60)^{\star} \\
0 \\
3 \\
3(60) \\
3 \\
0 \\
0 \\
2(40) \\
0 \\
2 \\
0 \\
3(60) \\
2(40) \\
0(0)\end{array}$ & $\begin{array}{l}23 \\
0 \\
17(74)^{\star} \\
3 \\
14 \\
17(74) \\
13 \\
2 \\
2 \\
11(48) \\
4 \\
5 \\
2 \\
12(52) \\
6(26) \\
5(22)\end{array}$ \\
\hline
\end{tabular}

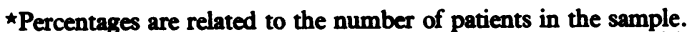

tAll patients with aortic regurgitation, isolated or associated with mitral prolapse.

fOnly patients with mitral valve prolapse alone.

OOnly patients with isolated aortic regurgitation. 
Table 3 Echocardiographic incidence of aortic dilatation according to different criteria ${ }^{\star}$

\begin{tabular}{|c|c|c|c|c|c|c|c|}
\hline & \multicolumn{3}{|c|}{ Male patients } & \multicolumn{3}{|c|}{ Female patients } & \multirow[t]{2}{*}{ Total (\%) } \\
\hline & $<16$ years & Adults & Total (\%) & $<16$ years & Adults & Total (\%) & \\
\hline $\begin{array}{l}\text { No of patients } \\
\text { Aortic dilatation }\end{array}$ & 4 & 19 & 23 & 2 & 4 & 6 & 29 \\
\hline $\begin{array}{l}\text { Two positive criteriat } \\
\text { Three positive criteria }\end{array}$ & $\begin{array}{l}3 \\
3\end{array}$ & $\begin{array}{l}17 \\
12\end{array}$ & $\begin{array}{l}20(87) \\
15(65)\end{array}$ & $\begin{array}{l}1 \\
0\end{array}$ & $\begin{array}{l}2 \\
1\end{array}$ & $\begin{array}{l}3(60) \\
1(17)\end{array}$ & $\begin{array}{l}23(79) \\
16(55)\end{array}$ \\
\hline
\end{tabular}

$\star$ See text for explanation.

†Table 5 gives number of patients with only two positive criteria.

Table 4 Fluttering of the anterior mitral leaflet determined by echocardiography

\begin{tabular}{|c|c|c|c|c|c|c|c|}
\hline & \multicolumn{3}{|c|}{ Male patients } & \multicolumn{3}{|c|}{ Female patients } & \multirow[t]{2}{*}{ Total (\%) } \\
\hline & $<16$ years & Adults & Total (\%) & $<16$ years & Adults & Total (\%) & \\
\hline $\begin{array}{l}\text { No of patients } \\
\text { Mitral valve fluttering }\end{array}$ & $\begin{array}{l}4 \\
1\end{array}$ & $\begin{array}{l}19 \\
11 \\
\end{array}$ & $\begin{array}{l}23 \\
12(52)\end{array}$ & $\begin{array}{l}2 \\
0\end{array}$ & $\begin{array}{l}4 \\
2\end{array}$ & $\begin{array}{l}6 \\
2(33)\end{array}$ & $\begin{array}{l}29 \\
14(48)\end{array}$ \\
\hline
\end{tabular}

Table 5 Prolapse of the mitral valve determined by echocardiography

\begin{tabular}{|c|c|c|c|c|c|c|c|}
\hline & \multicolumn{3}{|c|}{ Male patients } & \multicolumn{3}{|c|}{ Female patients } & \multirow[t]{2}{*}{ Total (\%) } \\
\hline & $<16$ years & Adults & Total (\%) & $<16$ years & Adults & Total (\%) & \\
\hline $\begin{array}{l}\text { No of patients } \\
\text { Mitral valve prolapse } \\
\text { Pansystolic } \\
\text { Mid-end systolic }\end{array}$ & $\begin{array}{l}4 \\
4 \\
2 \\
2\end{array}$ & $\begin{array}{r}19 \\
14 \\
9 \\
5\end{array}$ & $\begin{array}{l}23 \\
18(78) \\
11(61) \\
7(39)\end{array}$ & $\begin{array}{l}2 \\
2 \\
2 \\
0\end{array}$ & $\begin{array}{l}4 \\
3 \\
1 \\
2\end{array}$ & $\begin{array}{l}6 \\
5(83) \\
3(60) \\
2(40)\end{array}$ & $\begin{array}{r}29 \\
23(79) \\
14(61) \\
9(39)\end{array}$ \\
\hline
\end{tabular}

Table 6 Summary of echocardiographic findings and skeletal and ocular abnormalities

\begin{tabular}{|c|c|c|c|c|c|c|c|}
\hline & \multicolumn{3}{|c|}{ Male patients } & \multicolumn{3}{|c|}{ Female patients } & \multirow[t]{2}{*}{ Total (\%) } \\
\hline & $<16$ years & Adults & Total (\%) & $<16$ years & Adults & Total (\%) & \\
\hline $\begin{array}{l}\text { No of patients } \\
\text { Normal echocardiogram } \\
\text { Aortic dilatation only } \\
\text { Aortic dilatation }+ \text { anterior mitral } \\
\text { leaflet fluttering }\end{array}$ & $\begin{array}{l}4 \\
0 \\
0 \\
0\end{array}$ & $\begin{array}{r}19 \\
0 \\
0 \\
5\end{array}$ & $\begin{array}{l}23 \\
0 \\
0 \\
5(22)\end{array}$ & $\begin{array}{l}2 \\
0 \\
0 \\
0\end{array}$ & $\begin{array}{l}4 \\
0 \\
0 \\
1\end{array}$ & $\begin{array}{l}6 \\
0 \\
0 \\
1(16 \cdot 5)\end{array}$ & $\begin{array}{l}29 \\
0 \\
0 \\
6(21)\end{array}$ \\
\hline $\begin{array}{l}\text { Aortic dilatation + mitral valve prolapse } \\
\text { Aortic dilatation + anterior mitral } \\
\text { leaflet fluttering + mitral valve prolapse }\end{array}$ & $\begin{array}{l}2 \\
1\end{array}$ & $\begin{array}{l}6 \\
6\end{array}$ & $\begin{array}{l}8(35) \\
7(30)\end{array}$ & $\begin{array}{l}1 \\
0\end{array}$ & $\begin{array}{l}1 \\
1\end{array}$ & $\begin{array}{l}2(33) \\
1(16.5)\end{array}$ & $\begin{array}{r}10(34) \\
8(27)\end{array}$ \\
\hline $\begin{array}{l}\text { Mitral valve prolapse only } \\
\text { Skeletal abnormalitiest } \\
\text { Ocular abnormalitiest }\end{array}$ & $\begin{array}{l}1 \\
4 \\
2\end{array}$ & $\begin{array}{r}2 \\
16 \\
11\end{array}$ & $\begin{array}{l}3(13) \\
20^{(13)}\end{array}$ & $\begin{array}{l}1 \\
1 \\
1\end{array}$ & $\begin{array}{l}1 \\
4 \\
3\end{array}$ & $\begin{array}{l}2(33) \\
5 \\
4\end{array}$ & $\begin{array}{l}5(17) \\
25 \\
17\end{array}$ \\
\hline
\end{tabular}

The number of patients with aortic dilatation is reported on the basis of two positive criteria (see text).

*Includes the patients with aortic dissection and aortic regurgitation.

†atients are included with either increased metacarpal index or height span difference, or both.

$\ddagger$ Patients classified as having probable or possible signs of Marfan's syndrome are included.

terised by pansystolic prolapse, with no clear age and sex difference (Table 5). Mitral valve prolapse was usually associated with echocardiographic changes typical of aortic root dilatation (Table 6).

Dilatation of the left ventricle (Fig. 4) was present only in adults, almost all of whom were men with aortic regurgitation; one of these had aortic root dissection. This patient is included in the tables among cases with aortic dilatation and anterior mitral leaflet fluttering. Fig. 5 shows the typical pattern of aortic root dissection. ${ }^{1516}$ Left ventricular end diastolic diameter (mean $53 \pm 11.5 \mathrm{~mm}$ ) was increased, both as an absolute value and corrected for body surface area, in 10 patients $(34 \%)$, all of whom were adults - nine men and one woman.

One man had aortic dissection and aortic regurgitation, four men had both mitral valve prolapse and aortic regurgitation, three men and the woman' 
Table 7 Summary of data from the 18 patients with both polyechocardiographic and echocardiographic evaluation

\begin{tabular}{|c|c|c|c|c|c|c|c|}
\hline & \multicolumn{3}{|c|}{ Male patients } & \multicolumn{3}{|c|}{ Female patients } & \multirow[t]{2}{*}{ Total (\%) } \\
\hline & $<16$ years & Adults & Total (\%) & $<16$ years & Adults & Total (\%) & \\
\hline \multirow{2}{*}{$\begin{array}{l}\text { Polygraphic data } \\
\text { Click syndrome } \\
\text { Click syndrome + aortic } \\
\text { regurgitation } \\
\text { Aortic regurgiation }\end{array}$} & 3 & 5 & $8(53)$ & 1 & 2 & $3(100)$ & $11(61)$ \\
\hline & $\begin{array}{l}0 \\
0\end{array}$ & $\begin{array}{l}5 \\
2\end{array}$ & $\begin{array}{l}5(33) \\
2(13)\end{array}$ & $\begin{array}{l}0 \\
0\end{array}$ & $\begin{array}{l}0 \\
0\end{array}$ & $\begin{array}{l}0(0) \\
0(0)\end{array}$ & $\begin{array}{l}5(28) \\
2(11)\end{array}$ \\
\hline \multirow{3}{*}{$\begin{array}{l}\text { Echocardiographic data } \\
\text { Isolated mitral valve prolapse } \\
\text { Mitral prolapse }+ \text { aortic dilatation } \\
\text { Mitral prolapse + aortic dilatation } \\
+ \text { aortic regurgitation } \\
\text { Aortic dilatation + aortic } \\
\text { regurgitation }\end{array}$} & $\begin{array}{l}1 \\
2\end{array}$ & $\begin{array}{l}2 \\
3\end{array}$ & $\begin{array}{l}3(20) \\
5(33)\end{array}$ & $\begin{array}{l}0 \\
1\end{array}$ & $\begin{array}{l}1 \\
1\end{array}$ & $\begin{array}{l}1(33) \\
2(67)\end{array}$ & $\begin{array}{l}4(22) \\
7(39)\end{array}$ \\
\hline & 0 & 5 & 5 (33) & 0 & 0 & $0(0)$ & $5(28)$ \\
\hline & 0 & 2 & $2(13)$ & 0 & 0 & $0(0)$ & $2(11)$ \\
\hline
\end{tabular}

aortic regurgitation only, one man had mitral valve prolapse only. None the less, shortening fraction was never substantially altered, and mean rate of circumferential fibre shortening was normal in all, showing that left ventricular pump failure was not present. A paradoxical movement of the posterior aortic wall was found in only two cases (Fig. 2). The data from the 18 patients on whom both polygraphic and echocardiographic examinations were performed are summarised in Table 7.

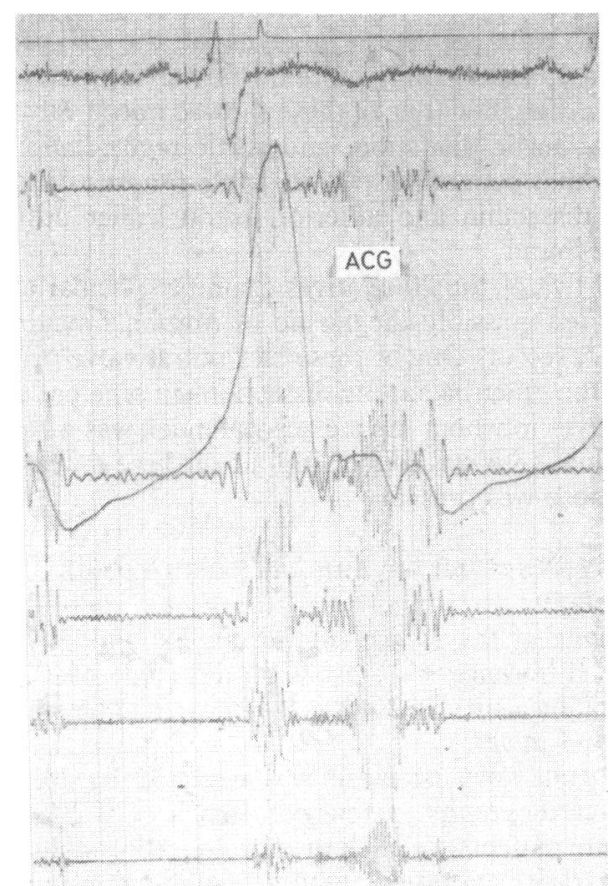

Fig. 1 Apexcardiogram in a 25 year old man with Marfan's syndrome. A mid-systolic notch, synchronous with a non-ejection click can be seen.
Skeletal and ocular findings

Height span differences were determined in 29 patients; 24 had a difference $\geqslant-7.6 \mathrm{~cm}$. The metacarpal index, determined in 20 , was $\geqslant 8.4$ in 18. Of the 24 ocular examinations, eight were considered as probably and 12 as possibly diagnostic of Marfan's syndrome.

Table 6 compares the cardiological, ocular, and skeletal abnormalities. In two boys under 16 years (cases 1 and 19 in Table 1) changes of all three systems

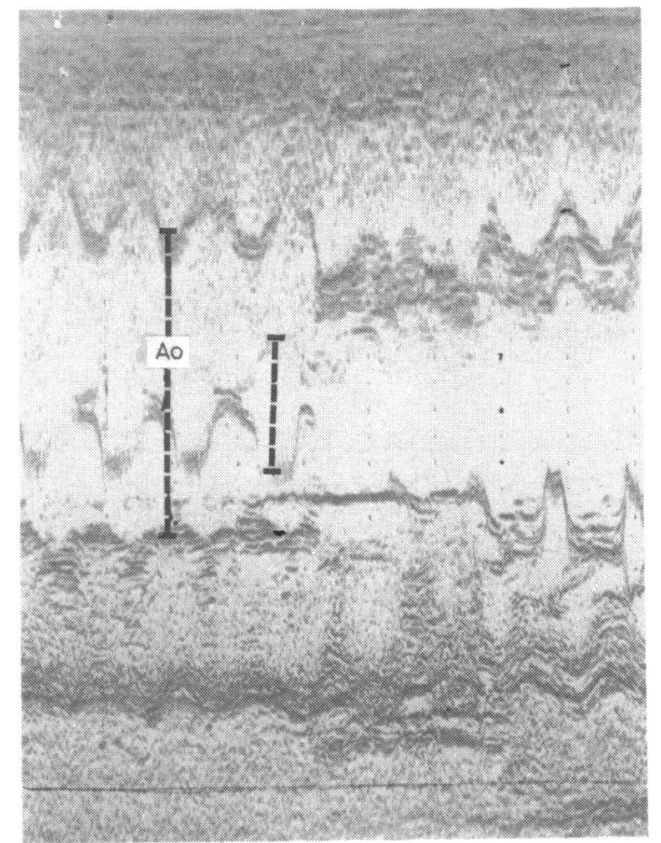

Fig. 2 Echocardiographic identification of paradoxical systolic movement of the posterior aortic wall in a 40 year old woman with Marfan's syndrome. The posterior wall shows a backward motion even after the maximal opening of the aortic valve (dashed line indicates the aortic box), continued until mid-ejection. Considerable aortic dilatation is present. 


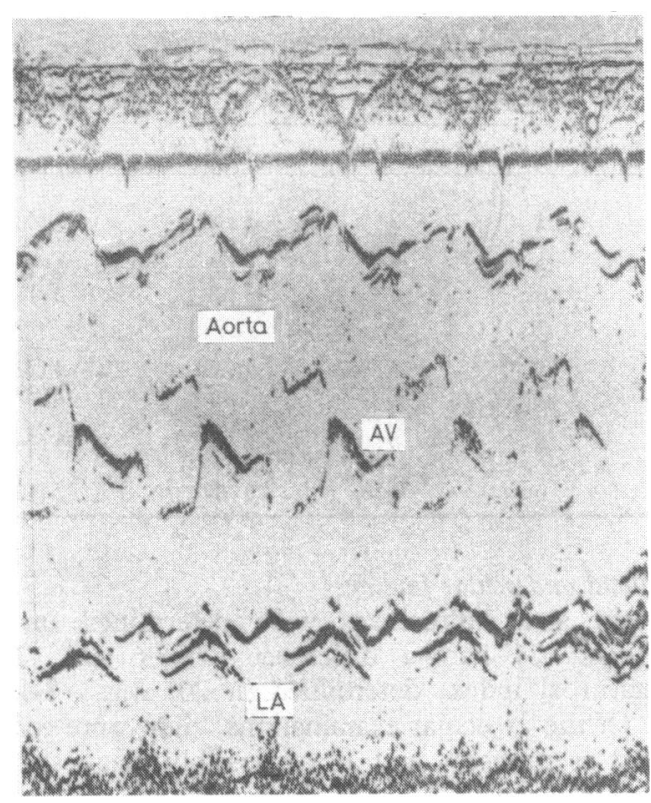

Fig. 3 Echocardiographic fondings in a 30 year old woman with Marfan's syndrome with severe aortic dilatation. AV, aortic valve; $L A$, lefi atrium.

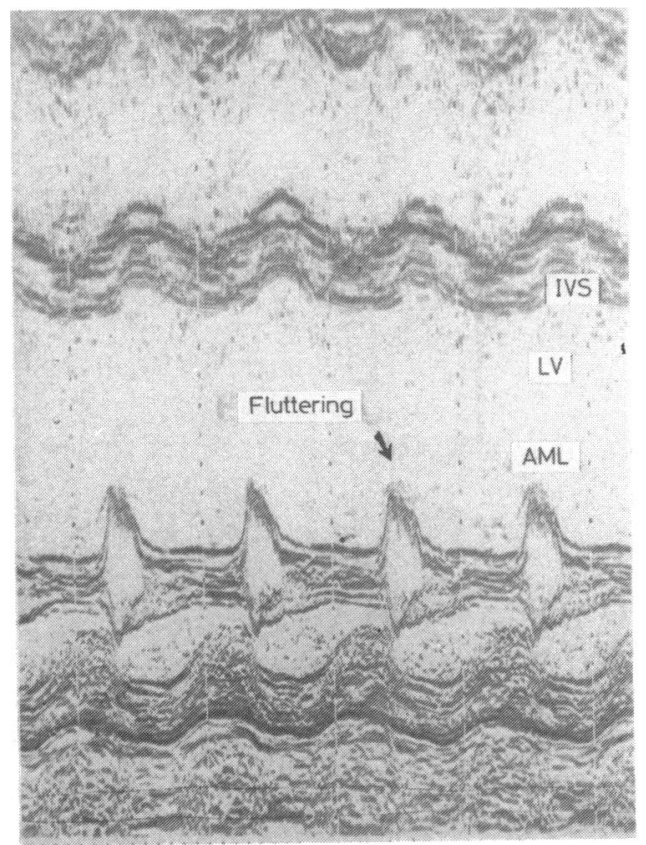

Fig. 4 Fluttering of the anterior mitral leaflet $(A M L)$ in a 40 year old woman with Marfan's syndrome. The left ventricle (LV) is considerably dilated. IVS, interventricular septum. were present; two boys under 16 years (cases 8 and 11 in Table 1) showed both cardiological and skeletal changes. A girl under 16 years (case 7 in Table 1) showed mitral valve prolapse, aortic dilatation, and ocular abnormalities; the other girl under 16 years (number 9 in Table 1) showed mitral valve prolapse and skeletal alterations. Among men, abnormalities of all three systems were present in nine, whereas seven others showed skeletal and cardiological changes, and two others showed cardiological and ocular signs of the disease (one of these two (case 30 in Table 1) had an aortic dissection). Somatic changes typical of the syndrome were present in one patient (case 16 in Table 1), in whom span and metacarpal index were not measured; at echocardiography mitral valve prolapse and aortic dilatation with aortic regurgitation were present. Three women had changes of all three systems and another woman had skeletal and cardiological abnormalities.

\section{RELATIVES (Table 8)}

Among the 32 relatives a mid-systolic click or systolic murmur, or both, was found on physical examination in 10 patients. In another, with aortic dissection, a diastolic murmur of aortic regurgitation was present, and in a further patient a pansystolic murmur of mitral regurgitation and diastolic murmur of aortic regurgitation were noted. Echocardiography showed mitral valve prolapse in eight of the 29 patients studied, and in three more mitral valve prolapse and aortic dilatation (one of these showed mitral valve prolapse, aortic dilatation, and aortic regurgitation); in one other patient (case 30 in Table 1) aortic dilatation and dissection and anterior mitral leaflet fluttering were found.

In two of the 20 relatives examined, ocular abnormalities, possibly diagnostic of Marfan's syndrome, were present. One of these had mitral valve prolapse and the other had aortic dissection. In seven of the 17 relatives in whom the metacarpal index was measured a value $\geqslant 8.4$ was found; in four of these mitral valve prolapse was present.

\section{PATIENTS WITH SEVERE KYPHOSCOLIOSIS} (Table 9)

In none of the 34 patients examined could a height span difference $>-7.6 \mathrm{~cm}$ be detected. Metacarpal index, measured in 20, was 8.4 in two and between 8.0 and 8.3 in six.

Mitral valve prolapse was detected by $\mathbf{M}$ mode echocardiography in four, all females $(18.2 \%$ of the female patients); a click or a prolonged systolic murmur was noted on polygraphic examination in 10. In eight patients with murmurs and without a midsystolic click, in whom $M$ mode echocardiography did not show mitral valve prolapse, pharmacological test- 


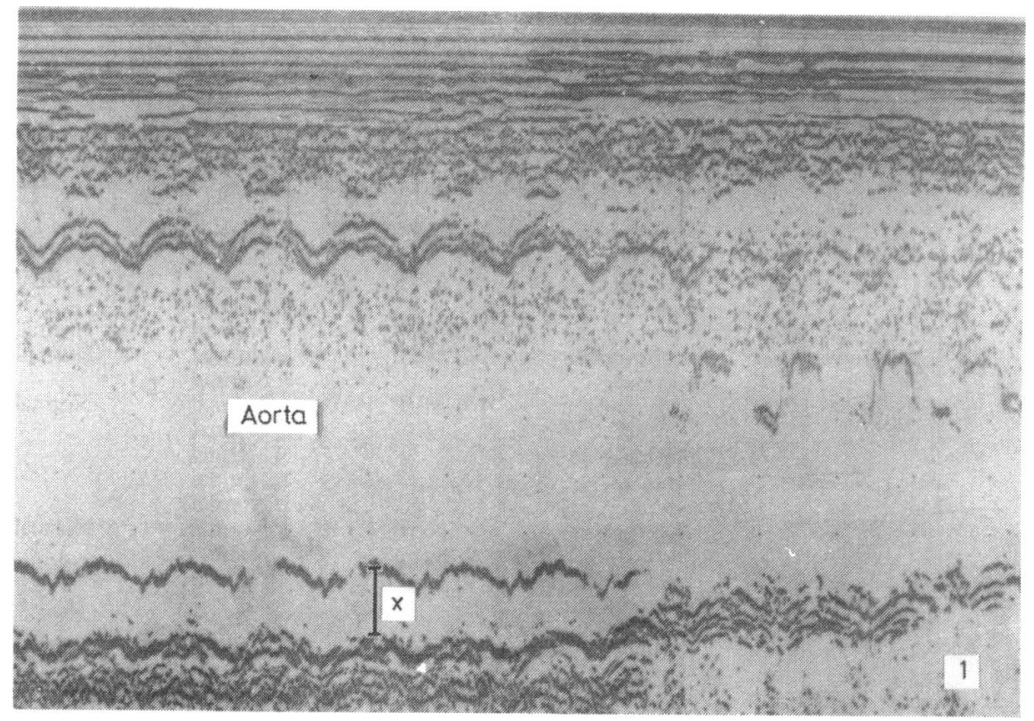

Fig. 5 Echocardiographic diagnosis of aortic root dissection in a 37 year old man with Marfan's syndrome. $X$ indicates the false aortic lumen.

Table 8 Cardiovascular, skeletal, and ocular data from relatives of patients with Marfan's syndrome

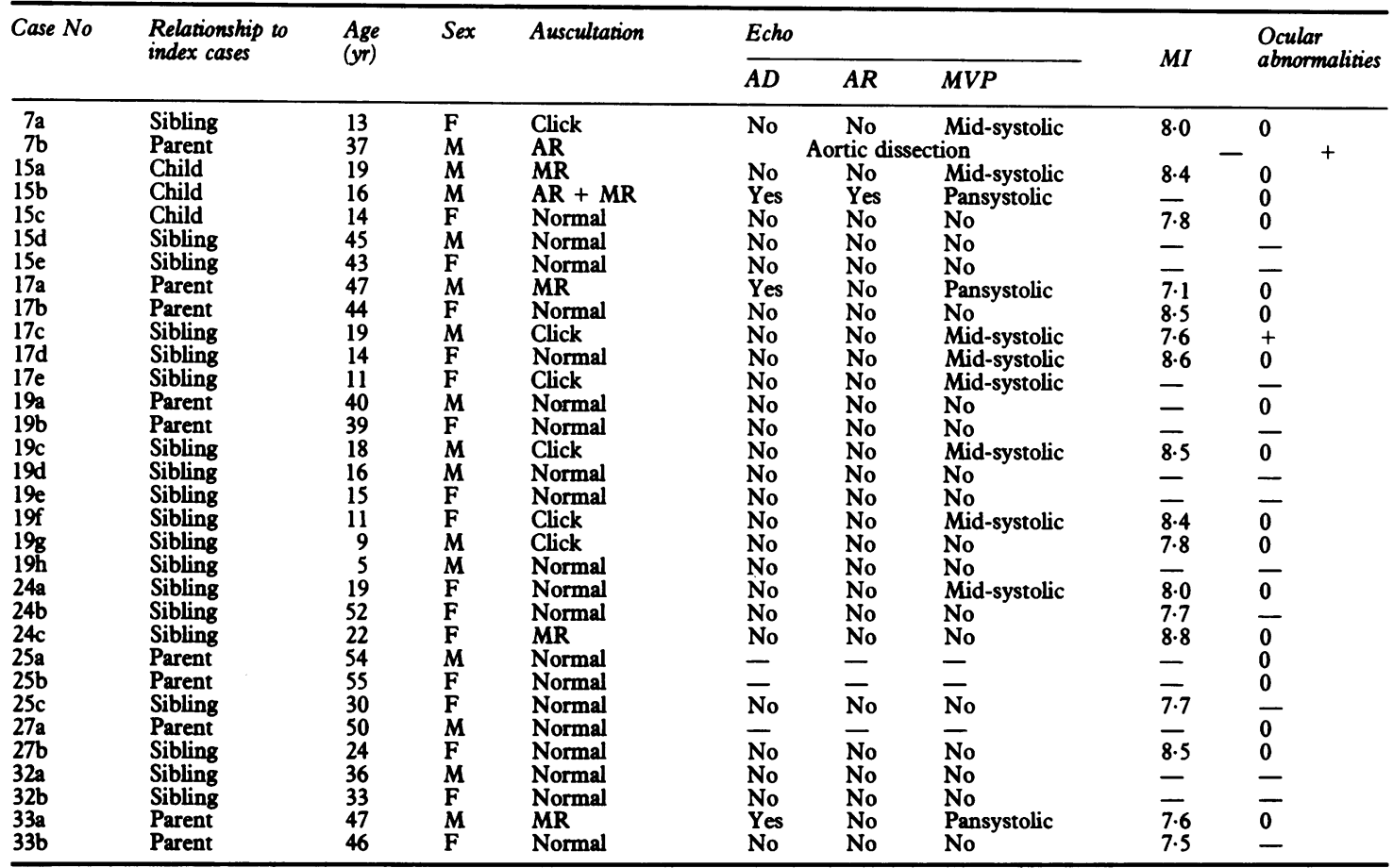

MVP, mitral valve prolapse; MR, murmur of mitral regurgitation; click, non ejection click; AR, aortic regurgitation; AD, aortic dilatation; MI, metacarpal index. Case $7 \mathrm{~b}=$ case 30 , case $15 \mathrm{a}=$ case 6 , case $15 \mathrm{~b}=$ case 20 , and case $24 \mathrm{c}=$ case 5 in Table 1 .

ing with amyl nitrite and methoxamine, together with cross sectional echocardiography, were performed. Amyl nitrite caused accentuation of the murmur in all of the patients studied; methoxamine did not modify or moderately reduced the murmur. Mitral valve prolapse was not detected by cross sectional echocardiography. In none with severe kyphoscoliosis could aortic dilatation or aortic regurgitation be found. 
Table 9 Cardiovascular and skeletal data from patients with severe kyphoscoliosis

\begin{tabular}{|c|c|c|c|c|c|c|c|c|c|}
\hline Case No & Sex & Age & $\begin{array}{l}\text { Height } \\
(\mathrm{cm})\end{array}$ & $\begin{array}{l}\text { Span } \\
(\mathrm{cm})\end{array}$ & $M I$ & $F C G$ & Methoxamine & $M$ mode echo & CS echo \\
\hline $\begin{array}{l}35 \\
36 \\
37 \\
38 \\
39 \\
40 \\
41 \\
42 \\
43 \\
44 \\
45 \\
46 \\
47 \\
48 \\
49 \\
50 \\
51 \\
52 \\
53 \\
54 \\
55 \\
56 \\
57 \\
58 \\
59 \\
60 \\
61 \\
62 \\
63 \\
64 \\
65 \\
66 \\
67 \\
68\end{array}$ & 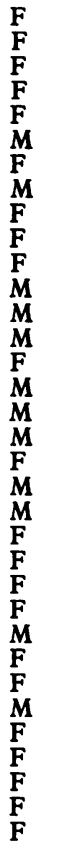 & $\begin{array}{l}11 \\
13 \\
14 \\
16 \\
15 \\
12 \\
12 \\
15 \\
23 \\
11 \\
13 \\
18 \\
14 \\
16 \\
11 \\
23 \\
21 \\
16 \\
14 \\
15 \\
14 \\
31 \\
23 \\
22 \\
14 \\
18 \\
15 \\
16 \\
13 \\
15 \\
14 \\
19 \\
19 \\
17\end{array}$ & $\begin{array}{l}154 \\
160 \\
162 \\
164 \\
166 \\
147 \\
140 \\
178 \\
165 \\
141 \\
150 \\
190 \\
172 \\
190 \\
139 \\
184 \\
183 \\
176 \\
160 \\
170 \\
152 \\
168 \\
158 \\
165 \\
155 \\
180 \\
164 \\
164 \\
160 \\
162 \\
160 \\
170 \\
165 \\
162\end{array}$ & $\begin{array}{l}148 \\
155 \\
160 \\
165 \\
169 \\
151 \\
141 \\
182 \\
169 \\
143 \\
150 \\
195 \\
175 \\
195 \\
140 \\
183 \\
185 \\
176 \\
162 \\
168 \\
154 \\
165 \\
160 \\
162 \\
158 \\
178 \\
162 \\
160 \\
163 \\
162 \\
160 \\
170 \\
165 \\
162\end{array}$ & $\begin{array}{l}8 \cdot 4 \\
6 \cdot 7 \\
7 \cdot 4 \\
8 \cdot 1 \\
7 \cdot 2 \\
\\
8 \cdot 0 \\
7 \cdot 6 \\
8 \cdot 4 \\
8 \cdot 1 \\
8 \cdot 3 \\
7 \cdot 6 \\
8 \cdot 2 \\
\\
8 \cdot 0 \\
7 \cdot 6 \\
7 \cdot 3 \\
7 \cdot 3 \\
7 \cdot 2 \\
7 \cdot 0 \\
7 \cdot 2 \\
7 \cdot 3\end{array}$ & $\begin{array}{l}\text { Normal } \\
\text { Syst murmur } \\
\text { Click } \\
\text { Syst murmur } \\
\text { Syst murmur } \\
\text { Syst murmur } \\
\text { Normal } \\
\text { Syst murmur } \\
\text { Syst murmur } \\
\text { Normal } \\
\text { Syst murmur } \\
\text { Normal } \\
\text { Normal } \\
\text { Normal } \\
\text { Normal } \\
\text { Syst murmur } \\
\text { Normal } \\
\text { Normal } \\
\text { Normal } \\
\text { Normal } \\
\text { Normal } \\
\text { Normal } \\
\text { Normal } \\
\text { Normal } \\
\text { Normal } \\
\text { Normal } \\
\text { Click } \\
\text { Normal } \\
\text { Normal } \\
\text { Normal } \\
\text { Normal } \\
\text { Normal } \\
\text { Normal } \\
\text { Normal }\end{array}$ & $\begin{array}{l}\text { No MVP } \\
\text { No MVP } \\
\text { No MVP } \\
\text { No MVP } \\
\text { No MVP } \\
\text { No MVP } \\
\text { No MVP } \\
\text { No MVP }\end{array}$ & $\begin{array}{l}\text { MVP } \\
\text { Normal } \\
\text { MVP } \\
\text { Normal } \\
\text { Normal } \\
\text { Normal } \\
\text { Normal } \\
\text { Normal } \\
\text { Normal } \\
\text { Normal } \\
\text { Normal } \\
\text { Normal } \\
\text { Normal } \\
\text { Normal } \\
\text { Normal } \\
\text { Normal } \\
\text { Normal } \\
\text { Normal } \\
\text { MVP } \\
\text { Normal } \\
\text { Normal } \\
\text { Normal } \\
\text { Normal } \\
\text { Normal } \\
\text { Normal } \\
\text { Normal } \\
\text { MVP } \\
\text { Normal } \\
\text { Normal } \\
\text { Normal } \\
\text { Normal } \\
\text { Normal } \\
\text { Normal } \\
\text { Normal }\end{array}$ & $\begin{array}{l}\text { Normal } \\
\text { Normal } \\
\text { Normal } \\
\text { Normal } \\
\text { Normal } \\
\text { Normal } \\
\text { Normal } \\
\\
\text { Normal }\end{array}$ \\
\hline
\end{tabular}

MI, metacarpal index; FCG, phonocardiogram; methoxamine, methoxamine test; CS echo, cross sectional echocardiogram.

\section{Discussion}

Essentially, all of the patients with Marfan's syndrome showed definite polygraphic and echocardiographic changes, usually diagnostic of mitral valve prolapse, which was either isolated or associated with dilatation of the aortic root. The results of this series are different from those reported by Brown et al, who found polygraphic abnormalities in only $54 \%$ of their patients-for example, they found systolic nonejection clicks and apical murmurs in $46 \%$ (39\% of the males and $58 \%$ of the females), without age differences. ${ }^{11}$ Diastolic murmurs of aortic regurgitation were also described by these authors in eight out of 35 (23\%), all males, and only one younger than 16 years.

The high incidence of abnormalities in our group may be explained by the history of subjective or objective symptoms, or both, prompting their referral to our centre. These patients are therefore a selected group, unlike the group of Brown et al, for which no selection criteria are reported. ${ }^{11}$ It is noteworthy that in our series all patients under 16 years had mitral valve prolapse, while none showed aortic regurgitation.

The carotid pulse tracing of patients with aortic regurgitation showed a bisferiens plateau in $55 \%$, with an adequate preservation of the dicrotic notch. ${ }^{17}$ The systolic time intervals were essentially normal in all except one. This finding differs from those reported by Sakamoto et al, who found an increased ratio of pre-ejection period to left ventricular ejection time in a greater proportion of their cases. ${ }^{18}$ This discrepancy may be accounted for by differences in the types of patients studied in the two series. It is possible that in the group studied by Sakamoto et al ${ }^{18}$ patients with haemodynamically significant mitral regurgitation or myocardial impairment, or both, were included. The a wave amplitude on the apexcardiogram was increased in $30 \%$ of our subjects, thus providing indirect evidence of a high left ventricular end diastolic pressure. A mid-systolic notch synchronous with the click was noted in $35 \%$. Particular attention was paid to isolated mitral valve prolapse, the commonest polygraphic finding in our series (52\%). This was, in fact, present in all six subjects under 16 years and in $40 \%$ of men and $50 \%$ of women. In contrast to observations by other authors, 1119 all patients with echocardiographic evidence of mitral valve prolapse had the polygraphic changes of the click syndrome (Table 7). 
Many patients with a definite mitral valve prolapse with aortic dilatation showed no clear signs of aortic regurgitation. Moreover, there was no correlation between aortic root diameter and echocardiographic or mechanocardiographic signs of aortic regurgitation. This lack of correlation may be due either to the difficulty in defining whether dilatation occurs eccentrically or the difficulty in estimating the degree of dilatation. Echocardiographic measurements of this type may, in fact, be subject to criticism, particularly in patients with Marfan's syndrome. Dilatation cannot be correctly estimated, the original diameter being unknown; if values are corrected for body surface area, as in our patients, they are only approximate in normal subjects and far less reliable in dysmorphic patients, such as those with Marfan's syndrome. The ratio of left atrium to aorta is not a reliable index either, the comparison being between two chambers which may be unevenly dilated.

Our echocardiographic findings seem to confirm previous observations ${ }^{311}$ that aortic changes may progress with age, leading to aortic regurgitation, an occurrence more common in males than in females. They also confirm the findings of the study by Murdoch et al on the different probability of survival related to age and sex. ${ }^{7}$ In our study aortic root dilatation and regurgitation were found in the absence of changes in the mitral valve, thus making mitral valve prolapse a common component of the syndrome, but not a constant observation. When no mitral valve abnormalities were present, we often found a greater degree of aortic root dilatation with aortic regurgitation, 20 suggesting a more rapid and unfavourable course. The general validity of this clinical observation is, of course, limited by the relatively small sample of patients with Marfan's syndrome as well as by the inaccuracy of the echocardiographic method of determining aortic dilatation.

Another objective of this study was an analysis of the abnormalities associated with Marfan's syndrome both in patients and in their relatives, as well as an evaluation of changes typical of Marfan's syndrome in patients with another type of connective tissue disease, kyphoscoliosis. In many of the patients with Marfan's syndrome, abnormalities of all three organ systems, or of the heart and the skeleton, were often associated. A less common association was that between ophthalmological and cardiological abnormalities. We did not, however, find a significant correlation between abnormalities in the three different systems: some patients showed severe skeletal changes with moderate cardiovascular changes; in others the opposite was found, thus confirming the variation in penetrance in the typical markers of the syndrome.

Our series of relatives also had a high percentage of cardiovascular abnormalities. Mitral valve prolapse was present in $38 \%$ and aortic dilatation with and without aortic regurgitation in $14 \%$. Seven of the 17 studied relatives had a metacarpal index $\geqslant 8.4(41 \%)$ and nine $(53 \%)>8.0$. These values, although lower than those found in patients with Marfan's syndrome, are certainly higher than those found in the general population. Four of the relatives reported in Table 8 and Table 1 had clearcut signs of Marfan's syndrome (the findings from the three propositi are reported only in Table 1). At least four other relatives might reasonably be considered to have a forme fruste of the syndrome. In our series ophthalmological abnormalities were less common, occurring in only two of the 20 relatives $(10 \%)$.

Of the 34 patients with severe kyphoscoliosis only two had a metacarpal index of 8.4 and only one of these showed echocardiographic and polygraphic evidence of mitral valve prolapse. Mitral valve prolapse was present in four (12\%), all women as it happened-that is, in a far lower percentage compared with patients with Marfan's syndrome and their relatives. No patient with kyphoscoliosis showed aortic dilatation and aortic regurgitation. The frequent presence of a prolonged systolic murmur often required the performance of pharmacological tests (the methoxamine test may be considered more relevant in this condition since methoxamine increases only the regurgitant murmur, whereas amyl nitrite increases both the ejection and the regurgitant murmur of mitral valve prolapse), as well as cross sectional echocardiography, to avoid misinterpretation and to determine the exact prevalence of mitral valve prolapse.

The $12 \%$ (18.2\% in females) prevalence of mitral valve prolapse in the patients with kyphoscoliosis is not easily compared with percentages found in other published work, the range of these being too large (from 0.3 to $21 \%)^{21-23}$ It has been argued that the best estimate for the prevalence of mitral valve prolapse in the general population is close to $4 \% 24$; by adopting this value, our kyphoscoliotic patients show a high prevalence of mitral valvulopathy.

The results of this study indicate that Marfan's syndrome has a definite pattern of inheritance, signs of the disease being far more common in the relatives of patients with Marfan's syndrome compared with the general population. The picture is less clear in patients with kyphoscoliosis, in whom cardiac abnormalities are less common, although more so than in the general population.

\section{References}

1 Eldridge R. The metacarpal index: a useful aid in the diagnosis of the Marfan syndrome. Arch Intern Med 1964; 113: $248-54$. 
2 Cross HE, Jensen AD. Ocular manifestations in the Marfan syndrome and homocystinuria. Am $\mathcal{F}$ Ophthalmol 1973; 75: 405-20.

3 McKusick VA. The cardiovascular aspects of Marfan's syndrome: a heritable disorder of connective tissue. Circulation 1955; 11: 321-42.

4 Lindsay J Jr. The aorta in Marfan's syndrome and in idiopathic dilatation of the ascending aorta. In: Hurst JW, ed. The heart. 3rd ed. New York: McGraw-Hill, 1974: 1588-94.

5 McKusick VA. Heritable disorders of connective tissue. 2nd ed. St Louis: CV Mosby, 1960.

6 Emanuel R, Marcomichelakis J, Moores EC, Jefferson KE, MacFaul PA, Withers R. Formes frustes of Marfan's syndrome presenting with severe aortic regurgitation. Clinicogenetic study in 18 families. $\mathrm{Br}$ Heart $\mathrm{f}$ 1977; 39: 190-7.

7 Murdoch JL, Walker BA, Halpern BL, Kuzma JW, McKusick VA. Life expectancy and causes of death in the Marfan's syndrome. N Engl F Med 1972; 286: 804-8.

8 Papaioannou AC, Agustsson MH, Gasul BM. Early manifestations of the cardiovascular disorders in Marfan syndrome. Pediatrics 1961; 27: 255-68.

9 Payvandi MN, Kerber RE, Phelps CD, Judisch GF, El-Khoury G, Schrott HG. Cardiac, skeletal and ophthalmologic abnormalities in relatives of patients with the Marfan syndrome. Circulation 1977; 55: 797-802.

10 Phornphuktul C, Rosenthal A, Nadas AS. Cardiac manifestations of Marfan syndrome in infancy and childhood. Circulation 1973; 47: 587-96.

11 Brown OR, DeMots H, Kloster FE, Roberts A, Menashe VD, Beals RK. Aortic root dilatation and mitral valve prolapse in Marfan's syndrome: an echocardiographic study. Circulation 1975; 52: 651-7.

12 Atsuchi Y, Nagai Y, Komatsu Y, Nakamura K, Shibuya $M$, Hirosawa $\mathrm{K}$. Echocardiographic manifestations of annuloaortic ectasia: its "paradoxical" motion of the aorta and premature systolic closure of the aortic valve. Am Heart f 1977; 93: 428-33.

13 Sinclair RJG, Kitchin AH, Turner RWD. The Marfan syndrome. $Q \mathcal{F}$ Med 1960; 29: $19-46$.

14 Duke-Elder S. System of ophthalmology. vol III. London: Kimpton, 1964.

15 Nanda NC, Gramiak R, Shah PM. Diagnosis of aortic root dissection by echocardiography. Circulation 1973; 48: 506-13.

16 Moothart RW, Spangler RD, Blount SG Jr. Echocardiography in aortic root dissection and dilatation. $A m \mathcal{F}$ Cardiol 1975; 36: 11-6.

17 Bruno L, Tredici S, Brusoni B, Mafrici A, Pezzano A. Sindrome di Marfan: studio ecocardiografico e poligrafico. G Ital Cardiol 1979; 9 (suppl 1): 159.

18 Sakamoto $T$, Ishimitsu $T$, Hada $Y$, Amano $K$, Yamaguchi T, Takenaka T. Systolic time intervals in mitral valve prolapse syndrome [Abstract]. Acta Cardiol (Brux) 1981; 36: 325.

19 Asin Cardiel E, Molinero F, Yuste P, Menárguez L. Valor de la ecocardiografia en el sindrome de Marfan. Rev Esp Cardiol 1978; 31: 259-64.

20 Bruno L, Tredici S, Mangiavacchi M, Mazzocchi F. Mechanocardiography and echocardiography in the knowledge of the evolution of Marfan syndrome. In: IX World Congress of Cardiology, Moscow 1982. [Abstract 0178].

21 Procacci PN, Savran SV. Schreiter SL, Bryson AL. Prevalence of clinical mitral-valve prolapse in 1169 young women. N Engl f Med 1976; 294: 1086-8.

22 Markiewicz W, Stoner J, London E, Hunt SA, Popp RL. Mitral valve prolapse in one hundred presumably healthy young females. Circulation 1976; 53: 464-73.

23 Rovelli F. Il prolasso della mitrale. G Ital Cardiol 1976; 6: $181-4$

24 Jeresaty R. Mitral valve prolapse. New York: Raven Press, 1979: 5. 